\title{
СТО ДВАДЕСЕТ ГОДИНА РАДА ДРАИНЦА
}

(Зборник радова са научног скупа Кюижевно дело Рада Драинияа - ново читағе, приредио проф. др Горан Максимовић, Ниш: САНУ, Огранак;

Филозофски факултет Универзитета у Нишу; Прокупље: Народна библиотека „Раде Драинац”, 2020 (Ниш: Светпринта), 203 стр.)

\section{Книжевно дело Рада Драинца - ново читане}

Симболичних сто двадесет година од рођења Рада Драинца (1899-1943) нису прошле незапажено ни у научном свету ни међу поштоваоцима његовог књижевног дела. Српском песнику није посвећен само зборник радова Кюижевно дело Рада Драиниа - ново читаюе већ је под истим именом одржан научни скуп 26. и 27. августа 2019. године у Нишу и Прокупљу у организацији Огранка САНУ у Нишу, Народне библиотеке „Раде Драинац” у Прокупљу као и Филозофског факултета Универзитета у Нишу. Повод научног скупа био је већ напоменути јубилеј: сто двадесет година од рођења српског књижевника као и обележавање педесет година постојања књижевне манифестације „Драинчеви дани” одржаване у Прокупљу у организацији Народне библиотеке „Раде Драинац".

Зборник радова Книжевно дело Рада Драинца - ново читаюе састоји се од четрнаест научних радова подељених у две концизно раздвојене целине. Након Садржаја (7-9), а пре самих радова, налази се Уводна реч (11-16) приређивача Горана Максимовића у којој се аутор обраћа читаоцима и излаже детаљне осврте на радове који зборник сачињавају.

Рад који отвара зборник насловљен је идентично као и наслов самог зборника и научног скупа: „Раде Драинац - једно ново читање” (17-30) чији је аутор Јован Делић. Делић Драинца сагледава првенствено кроз призму хипнизма (Драинчев покрет) с тим да га сагледава и у 
контексту српске песничке авангарде, експресионизма, дадаизма и надреализма. Делићево ново читање Драинца је другачије и ново усредсређивање на поетику поменутог аутора, али је боље рећи да Делић открива Драинчеву поезију на начин „новог доказног поступка” (17) на коме је рад и конципиран. Наиме, анализирају се стихови 10. песме „Еротикона”, песме „Нирвана” и „Пикова дама” са сталном тенденцијом отварања истраживања ка Драинчевим збиркама песама које аутор појединачно вреднује, периодично класификује и аналитички разлаже. Анализу Драинчевих песничких остварења Делић допуњује и успостављањем односа према другим ауторима: J. Дучићу, В. П. Дису, Р. Петровићу, М. Црњанском. Предмет рада „Путописна проза Рада Драинца” (31-50) аутора Горана Максимовића јесте Драинчев путописни поступак у прозним записима. Максимовић говори о приказивању два доминантна путописна света - о српским покрајинама и јужнословенском поднебљу као и о европским земљама и градовима. Драинчева путописна проза у виду записа и репортаже била је објављивана у тадашњим српским и југословенским листовима и часописима у периоду између 1923. и 1935. године. Аналитичким приступом одабраног корпуса и анализом самог приповедног/путописног поступка, Максимовић истиче две главне особине Драинчевог писања: прва особина путописног поступка је приказ старих и нових, познатих и непознатих простора које по први пут види, а друга особина се може посматрати кроз карактеризацију необичних људи које сусреће и пратећих дешавања и авантура. Аутор анализу започиње од записа „Човек путује” (1935), „Лето у Топлици” (1924), „Железница кроз Топлицу” (1925), „Јесен у Скопљу” (1929) док и у осталим многобројним записима истражује основне теме, разне појаве, авантуре, догађаје, описе градова и простора, карактеризације ликова посматрајући и записе један наспрам другог нудећи на тај начин читаоцу својеврсну географску путању Драинчевих кретања (Драинчевог живота уопште) пропраћену аутобиографским појединостима.

На који начин, у којој мери и о каквим појединостима Стеван Раичковић говори кроз своје дневничке записе о Раду Драинцу, тема је рада Снежане Милосављевић-Милић „Линија магле и Волшебни саговорник - Раде Драинац у есејима Стевана Раичковића” (51-62). Ауторка анализу конципира на Раичковићевим есејима: „Трагом Драинца” (1960), „Драинац” (1974) и „О Драинцу” (1996) у којима уочава критичке елементе упућене Драинчевом поетском говору с тим да захваљујући овим есејима стичемо увид у стваралаштво Драинца и из различитих и из опречних перспектива. Раичковићеви дневнички записи одишу неминовном амбивалентношћу коју је аутор есеја имао према Драинцу - они су и афирмација и делимична негативна запитаност над Драинчевим де- 
лом. Милосављевић-Милић указује управо на те сегменте есејистичког говора о Драинцу настојећи да укаже и на неоспорну везу између двојице песника као и на елементарне утицаје Драинца осликане у поетском раду Стевана Раичковића. Рад „Драинчева кратка проза у контексту српског експресионизма друге и треће деценије 20. века" (63-75) ауторке Бојане Стојановић Пантовић скреће пажњу на вредност Драинчеве кратке прозе истичући авангардно-експресионистичке, тематско-мотивске, наративне и стилске вредности. Средиште анализе јесте Драинчева збирка кратке прозе „Срце на папиру” која садржи три приче „Свирач из плаве собе”, „Срце на пасату” и „Сабласни пацови” за које ауторка Стојановић Пантовић сматра да су репрезентативне за Драинца као прозаисту, али и за успостављање аспеката експресионистичко-авангардне прозе двадесетих и тридесетих година у српској књижевности. Ауторка анализира и кратке романе „Пламен у пустињи” (1928/1993), „Шпански зид” (1930) и „Наша љубав” (1930) бавећи се топосима посрнуле жене проститутке, трансформацијама романтичне љубави, питањима љубави према проститутки успостављајући корелацију са немачко-аустријским експресионизмом, француским надреализмом и футуризмом. Романи одишу авангардним, фрагментарним, дисконтинуираним и есејистичко-критичким наративом као и тематском ексклузивношћу чије елементе ауторка предочава компаративним сучељавањем ова три романа Рада Драинца.

Аутор Душан Живковић у раду „Значај Драинчеве поезије у контексту светске књижевности" (77-89) уочава поетске иновације у стваралаштву Драинца које одговарају водећим токовима светске књижевности између Првог и Другог светског рата. Полазећи од успостављања најстаријих митопоетских елемената чија је основа дијалог са традицијом и авангардним током уопште, Живковић првенствено дефинише опште елементе херметизма у Драинчевој поезији скрећући пажњу на утицај Вијонове поезије на Драинчеву поезију. Бавећи се култом уклетог песника, аутор доводи у везу француског симболисту Бодлера и Драинца уочавањем блискости односа двојице песника према смрти, према природи (јесени), али и према могућим алхемичарским процесима какви су својствени Артуру Рембоу. Живковић указује и на утицај Јесењинове поезије као и на мотивске идентичности између двојице песника, показује у којој мери је Мајаковски имао утицаја на Драинца и на који начин је Драинчев хипнизам антиципирао будуће токове светске књижевности у надреалистичким везама са поетским изражавањем подсвести. Прецизније, Живковић реченицу из „Програма хипнизма” из Драинчевог првог броја „Хипноса” доводи у неоспорну везу са Бретоновим (првим) Манифестом надреализма. Завршни рад прве целине радова јесте рад ауторке Светлане Рајичић Перић „Женско као пол и род - од еротичности / васељене 
до града кроз мотив дојки у поезији Рада Драинца" (91-108). Циљ рада је сагледавање еротичности, односно, разматрање семантике синонима дојки у контексту Драинчевог, али и опште авангардног радикализма. Авангардни радикализам тиче се поетске слике женског, поларизовања категорија пола (као биолошке чињенице) и рода (као друштвеног конструкта) у успостављању опозитних надреалних (91) светова утопије и антиутопије, природе/културе и цивилизације у поезији Рада Драинца.

Друга целина радова зборника о Драинцу започиње радом „Мариолошки аспекти песме „Љубав, Марија!” Рада Драинца” (109-119) аутора Ђорђа М. Ђурђевића који бавећи се у наслову поменутом песмом, преиспитује вишеструку фигуру жене са аспекта њене телесно-еротске стране и са аспекта жене као оваплоћења сотериолошке жеље за будућношћу и опраштањем. Наспрам библијске фигуре Марије, Ђурђевић васпоставља именовану Марију Драинчеве песме кроз преиспитивање мариологије која у Драинчевом случају долази након сваког одбацивања религиозног (112). Теопоетичка укрштања које аутор препознаје активирају преиспитивање целокупног дискурса, песме „Љубав, Марија!” која бива призивана и ишчитана на вишем религијско-семантичко-поетичко-мариолошком нивоу. Раде Драинац као зачетник свог хипнистичког правца, хипнизма, и разматрање хипнизма у односу према зенитизму и суматраизму тема је рада ауторке Јелене С. Младеновић „Драинчев „Програм хипнизма" у контексту авангардних програмских текстова и његова улога у часопису Хипнос" (121-132). Младеновић најпре прати Драинчев пут након Првог светског рата и прве збирке „Модри смех” (1920) настојећи да укаже на његов тадашњи положај и подвиг у контексту актуелних културних и уметничких тенденција. Као авангардни стваралачки императив, хипнизам је „идеална литерарна реализација тежњи зенитистичког покрета, самостално обликована и огрнута формом идентичности" (123). Ауторка указује на односе трију -изама: суматраизма, зенитизма и хипнизма, на њихове сличности, разлике, позиционирања у критици детаљно говорећи о „Програму хипнизма” објављеном у Драинчевом часопису „Хипнос” 1922. године. Питање или боље речено, разлог хипнизма је потреба за неприпадањем ниједној постојећој уметничкој теорији. Напротив, тежи се стварању новог књижевног правца само што је противуреченост почивала у чињеници да одбацивањем постојеће теорије не би ли се створила нова, доспева се до немогућности да се истовремено „буде против теорије и да се створи некаква врста програмског оквира" (124) - све је, дакле, водило дезинтеграцији.

Часлав В. Николић, аутор рада „Размак од сто лета: биће и време у поезији Рада Драинца" (133-143) симболично указује на поновно перципирање Драинца у односу на епохалну дистанцу која дели данашњи- 
цу од времена његовог стварања. Захваљујући том епохалном размаку, том отклону па поновном враћању песмама Рада Драинца омогућено је оно разматрање пост- : након живота, након смрти, наком -изама, након искуства, након бића, након времена. Николић управо сажима тај епохални размак настојећи „да мисли” Драинчево биће, време и песништво. У контексту филозофије М. Хајдегера која се бави разоткривањем целовите могућности егзистенције и „онтолошке темпоралогије” (139), Николић спочитава моћи-бити Драинчевих стихова. Аутор показује како је Драинчева поетска артикулација „временски вишедимензионална, али и онтолошки вишедимензионална" разматрајући од чега је сачињено и шта је уопште оно 'између': „између часа субјектовог садашњег изговарања и будућег испуњења, односно између часа нашег садашњег откривања у читању и песничког прошлог започињања - али је разлика у томе што то „између”јесте у говор-време претворено субјектово „моћибити” (141). Та уочена инстанца „поствремена” својствена Драинчевом песништву достигнута је након физичке смрти и краја живота, а наступа унутар метафизичког трајања песничког бића. Испитивање авангардних прожимања хипнизма и даде на релацији две поетике: Драинчеве и поетике Драгана Алексића, тема је рада „Међу дадом и мед сном: дадаистички оквири Драинчевог хипнизма" (145-154) аутора Владимира Б. Перића. Супротстављањем и приближавањем ставова Драинца и Алексића, Перић полази од фигура сна, детета, еротског и урбаног показујући на који начин Драинчев хипнизам посматра сан и тело, на који начин постоји деструкција код Драинца и на који је начин и зашто она дадаистичка. Завршни део овог рада посвећен је успостављању паралела између постдадаизма (Алексићев позни дадаизам) и хипнизма који обележени збиркама „Еротикон” и „Воз одлази” чине заправо „један исти стилогени комплекс" (151) што значи да су они, како аутор закључује, једна иста стилска формација. Ауторка Аница М. Радосављевић у раду „Песничка мисао Рада Драинца - бунт против програмских ограничења једног времена" (155-166) бави се одређивањем песничких особености и програмских опредељења Драинца указујући на чињеницу да је његов опус - од прве збирке „Модри смех” (1920) до последње „Дах земље” (1940) првенствено изграђен на међуратном песничком искуству, осећању рата и на снажном модернистичком погледу на свет (159). Ауторка посебну пажњу поклања Драинчевој побуњеничкој поезији која је „била начин Драинчевог живота и људске егзистенције” (161). Побуњенички ставови према свом животу, унутрашњем бунту, свету око себе, околини, држави, моралу и вери показани су и пропраћени одломцима песама и коментарима ауторке која закључује да је та побуна у поезији заправо била тежња и жеља за препородом српске књижевности, друштва и културе, а 
да је време у коме живимо данас оно време у којем Драинчево дело живи више него икада.

Мање је познато да се Раде Драинац (Радојко Јовановић) поред књижевног стварања бавио и новинарством и критиком. Драинчев критичарски рад, усмерен пре свега ка позоришту у периоду када је песник боравио у Скопљу, тема је рада „Раде Драинац као позоришни критичар” (167-177) ауторке Милене Ж. Кулић. Ауторка настоји да покаже зашто би историја грађе о позоришту и историја нашег театра била далеко сиромашнија и непотпунија да не постоји позоришне периодике и у њој, између осталих, и текстови Рада Драинца (168). За Драинца је позоришна критика била посебна врста „казалишне књижевности” (169) и као таква, она је у уској вези са позоришним животом те аутор говори како је Драинац често присуствовао представама у редитељској ложи и боравио са глумцима. Један од позоришних текстова Драинца посвећен је обележавању четрдесетогодишње глумачке каријере Лујзе Станојевић. Такође је писао и о глумцу-комичару Душану Цветовићу. Написао је опширан осврт о раду Скопског позоришта, али је текстом „Шетња кроз архиву Народног позоришта у Београду” указао и на развој позоришта у Београду повезујући га са Скопљем. Аутор Борис Лазић је у раду „Поводом превода песама Радета Драинца на француски” (179-183) одговорио зашто је и на који је начин извршен избор и препев Драинчевих песама на француски језик. Настојања преводилаца (прим. Б. Лазића) била су да препевом на страни језик пруже увид у целокупно Драинчево песништво, да обухвати све од „Модрог смеха”, „Даха земље”, појединачних песама које се први пут појављују у његовим „Сабраним делима” па све до збирки „Бандит или песник” и „Банкет”. Превод песама аутор је посветио Гојку Тешићу који му је помогао приликом одабира песама. Иако је издање превода двојезично, као основни проблем сваког превода намеће се језик, али француски језик је својом устаљеном формом и једним синтаксичким и морфолошким системом ипак био погодан за превод Драинчевих песама. И сам Драинац је као ђак, како Лазић сматра, у Француској усвојио француски језик без обзира на то што је његов матерњи језик имао другачију историју. На пољу прозодије, Драинац је у том тренутку био под снажним утицајем француског језика (180). Аутор је настојао да веродостојно преведе све поетске слике на исти или приближан начин поштујући и риме где је било потребно као и асонанце, алитерације, анафоре и паралелизме на којима уопште и почива Драинчев слободни стих. Париз и француски језик су „друго песниково ја” (182), они су од Радојка Јовановића начинили авангардног песника Рада Драинца који и када се вратио у Србију, повремено је путовао у Француску. Тај биографски тренутак осликан у непрестаним додирима са француским језиком, фран- 
цуском културом наглашава ова антологија превода песама.

Ауторка Мирјана Бојанић Ћирковић у раду „Топлица у делу Рада Драинца" (185-203) уочава важност места рођења овог песника и сматра да аналаза репрезентација Топлице у Драинчевом делу осветљава једно ново лице драинизма указујући и на важност симболичности упадљивости боја у делу овог књижевника. Топлица је тематски оквир Драинчевог стваралаштва - како песничког, тако и прозног. Пролеће је један од доминантних мотива Драинчевих дела о Топлици, а ауторка указује на симболичка места Драинечвог животног и уметничког пута које су у вези са пролећем. Збирка „Модри смех” говори о Топлици и она је оцртала најмање два важна поетичка елемента Драинчевог стваралаштва, а то су пут (трагање) и плави (модри) узлет. У „Модром смеху” ауторка истиче плаву боју топличког неба, затим, реке које попримају модру боју шума, а модро је боја унутрашње запитаности. Ауторка анализира збирку „Модри смех” бавећи се симболичко-семантичким рашчитавањима доминантних мотива збирке истичући градирање мотива плаве боје преко ведре до модре надовезујући се на остале мотиве боја (првих назнака црвене боје), појаве мотива јесени, итд. Бојанић Ћирковић се бави и збирком „Улис” (1938) - „Улис је збирка стихова са песничког пута ван тла модре Топлице” (193). У овој збирци, модра боја дубине неба прелива се у црну боју земље - мајке. Збирка песама „Дах земље” (1940) као средишњи мотив има јесен (поред мотива виолине и јабуке које ауторка истиче) у виду разноврсне дескрипције јесени у родном селу. Што се Драинчеве прозе и топоса Топлице у њој тиче, Бојанић Ћирковић указује на кратки прозни текст „Наша љубав” (наглашена зелена боја) и на роман „Шпански зид” (и плава и бела боја) чијим анализама приводи крају овај исцрпан и детаљан осврт на Драинчево дело.

Говорећи о Драинчевој збирци „Улис”, Мирјана Бојанић Ћирковић као кључну реч ове збирке истиче реч ЧОВЕК - јер „човек је прва и последња реч” („Улис”) - „човек је песник корака и пута; човек је - пут.” (195). Стваралаштво и рад Рада Драинца је специфични облик (да не кажемо форма) nуma - његов опус разгранате су стазе скројеног животног, емотивног, песничког и књижевног пута коме су се аутори овог зборника препустили истражујући досад неотворене и оригиналне теме које крије Драинчево дело. Осим што су скретањем пажње на Драинчеву реч дали одговоре, али и отворили нова питања, аутори зборника су се такорећи надовезли на Драинчев песничко-прозно-путописни пут истичући зашто не сме и зашто неће нестати стваралаштво Рада Драинца из наше књижевно-културне свести. Пут ЧОВЕКА, Рада Драинца, и даље траје. Најбољи показатељ тога је, послужићемо се речима Часлава Николића, поменута „епохална дистанца” након које је остварено уистину ново чи- 
тање, ново спознавање и ново разумевање Драинчевог дела. Допринос научној заједници је овим зборником вишеструко остварен: почевши од одабира централне теме преко разноврсних и оригиналних научних приступа до аутентичних и „отворених” резултата који ће увек моћи да буду упоришта нових истраживања.

Александра В. Чебашек

Универзитет у Крагујевцу

Филолошко-уметнички факултет

Центар за проучавање језика и књижевности aleksandra.cebasek@filum.kg.ac.rs 